\title{
ADAPTATION OF LAW AS THE MODE OF THE INTERACTION OF LEGAL SYSTEMS
}

\section{Kharytonova O. I.}

\section{INTRODUCTION}

The influence of some legal systems on others and the interaction there of has long attracted the attention of jurists. The most popular the subject-matter of special studies investigate the influence of one law on another was the reception of Roman law, especially of scholarly inquiries from the Middle Ages onwards, and, after them, during the Great European codifications.

Analysis of the conceptions expressed in the process of investigating the influence of Roman law on the legal systems of western Europe seems inadvisable given that the very process of borrowing ideas and provisions of Roman law already have been the subject-matter of special scholarly works and received proper illumination there ${ }^{1}$.

Therefore we dwell merely on basic provisions relating to understanding the essence of the reception of Roman law in Europe.

Productive was the reception of Roman law in the late Middle Ages, when the views of Thomas Aquinas became the methodological foundation thereof. His concepts concerning the correlation of natural (divine) law and human (positive) laws, and also that it was necessary only to comply with those secular laws which were not contrary to natural law, actually served as the basis of the reception of Roman law in the form of practical application.

In the process of discussions relating to the suitability of Roman law for application in law-creation and legal life which took place before and during the great European codifications of the eighteenth and nineteenth centuries, European jurists formulated a number of propositions important in principle with regard to comprehending the essence of the phenomenon of the reception of Roman law (chiefly, of a compromise character).

Savigny insisted that law is never formed according to one's wish because it is a product of the development of the people's spirit which is revealed in the history of a people, in connection with its religion, culture, and so on.

${ }^{1}$ Муромцев С. Рецепция римского права на Западе. М.: Тип. А. И. Мамонтова и К, 1886.; Бек В.А. Рецепция римского права в Западной Европе: автореф. дисс. ... канд. юрид. наук. Львов, 1950.; Харитонов С.О. Рецепція римського приватного права (теоретичні та історико-правові аспекти). Одеса, 1997; Харитонов Є.О., Харитонова О.І. Рецепції приватного права: парадигма прогресу. Кіровоград: Центр.-Укр. вид-во, 1999; Томсинов В.А. Рецепция Римского права в Западной Европе”. Древнее право. 1998. №. 1. С. 169-175. 
Considering law in its historical development, Savigny and his pupils concentrated efforts on studying the Roman law of antiquity as set out in sources systematized by Justinian, supposing that this treasure house of imperishable legal values after proper processing might be applied directly as law in force. The task of jurists is merely to order, process, and improve abstract concepts ${ }^{2}$.

Rudolf von Jhering ${ }^{3}$, a consistent opponent of von Savigny, believed on the basis of an understanding of law as the direct product of life that ever greater changes in social life entail changes in the domain of law. He emphasized in so doing that not only national forces and the potential of each people have importance, but also the encounters thereof with others, borrowing. A people craving national exclusivity thereby condemns itself to stagnation. The task of the modern jurist is not only to create, but also to destroy, that is, discard the unnecessary and obsolete. The general methodology was then defined: Durch das römische Recht über aber das römische Recht hinaus ${ }^{4}$.

These conceptual approaches became the foundation for discussions when codifying German civil law. The conception of the Civil Code (BGB) was formed in a competition between the "Romanic-Pandectian" and "Germanic" approaches. After a mitigation of the Romanic principles, a draft was adopted in 1896 by a Union Council and confirmed by the Emperor. He entered into force on 1 January 1900. The actual preparation, discussion, and adoption thereof became a reflection of the comprehension of the essence of the reception of Roman law at the turn of the centuries.

\section{General provisions on the reception of Roman private law}

It should be noted that the interest of jurists of the Russian Empire in the reception of Roman law had a "dual" character. On one hand, this phenomenon they investigated as being inherent in Western culture. The significance of Roman law was determined by the fact that it comprised a vital, practical element of modern positive legislation and was the basis for a single science of civil law. "Reception was the mastery of Roman law by other peoples". 5 It was regarded as an element of a more general process of borrowing the achievements of a highly-developed ancient culture, and as a legal phenomenon, the borrowing of its provisions was explained by the need

\footnotetext{
${ }^{2}$ Новгородщев П.И. Историческая школа юристов. СПб.: Лань, 1999. С. 101-108.

3 Иеринг Р. фон. Историческая школа юристов. В кн.: Савиньи Ф.К. Система современного римского права: пер. Г. Жигулин. 2011. С. 73-101.

${ }^{4}$ Иеринг Р. фон. Дух римского права В кн.: Избранные труды. СПб., 2006. Т. II. С. 37-38.

${ }^{5}$ Азаревич Д.И. Из лекций по римскому праву. Одесса, 1885. С. 103; Азаревич Д.И. Значение римского права. Одесса, б.г.
} 
to use "more precise" norms for the regulation of a number of relations than those which existed in customary law of the majority of western European countries.

On the other hand, the subject-matter of scholarly studies was the problem of establishing the significance of Roman law for the legal system of the Russian Empire. M.L. Diuvernua, justifying the advisability of Russian jurists having recourse to Roman law, among its advantages he named its universality and abstractness, stressing that Roman law is the "most universal law" among other systems of law suitable for application in different countries $^{6}$. These conclusions found practical confirmation in the process of preparing the draft Civil Code in the Russian Empire. The drafting work became an important factor in the growing interest in Roman law and the investigation there of from the standpoint of possible use of its merits when improving legislation in force. On the whole, the fact of the reception of Roman law in Russia during the nineteenth and early twentieth century's generates no doubts among researchers ${ }^{7}$.

We may conclude that the conception of the reception of Roman law in European jurisprudence was formulated before the end of the nineteenth century and that it was the result of a comprehension of the essence of this phenomenon and evaluations of the possibility of its use in the process of preparing codifications, especially in the domain of civil law of the eighteenth and nineteenth centuries.

In the early twentieth century studies in this domain were fewer: the western vision of the essence of the reception of Roman law on the whole had been formed. The subject- matter of research became determining the place of Roman law in the culture of Europe, the reception of Roman law in individual countries, under special conditions, and so on ${ }^{8}$. The existence of a crisis in this domain was recognized and was a turning point in the quest for new orientations of research ${ }^{9}$.

The situation was otherwise in Eastern Europe, where the Soviet State arose whose legal doctrine was based on a Marxist-Leninist world outlook which denied succession of socialist law from the "law of an exploitative society". Therefore, the question of the reception of Roman law did not arise,

6 Дювернуа Н. Значение римского права для русских юристов. Ярославль: Тип. Г. Фальк. 1872. С. 14.

${ }^{7}$ Летяев В.А. Рецепция римского права в России XIX-начала XX в. (историко-правовой аспект): автореф. дисс. ... доктора юрид.наук. Саратов. 2001.

${ }^{8}$ Koschaker P. Europa und das römische Recht. 1958.

${ }^{9}$ Koschaker P. Die Krise des römischen Rechts und die romanistische Rechtswissenschaft. 1938. 
which predetermined a lessened interest in the last and in general in researching the achievements of "presocialist" systems of law.

The renaissance of studies of Roman law and its reception occur in the USSR only from the mid-1980s, when political, social, ideological, and legal reforms conditioned the enhanced interest of society in general humanitarian values, the heritage of other systems of world outlook, law, and so on.

The majority of jurists assessed the reception of Roman law from traditional positions, describing it as a phenomenon typical for all of continental Europe and Scotland and consisting of the comprehension and mastery of the Roman legal heritage as law in force ${ }^{10}$ or as a phenomenon which relative to the position of Roman law in feudal and bourgeois Europe represented a renewal of actions, borrowing, selection, processing, and mastery ${ }^{11}$.

The general reception of Roman law is evaluated as a phenomenon reflecting the influence of this "mother" legal system on the law of later times, a result of which was the forming and improving of modern European legal systems. In Ukrainian civilistics on the whole positive evaluations of this phenomenon predominate, to which the appearance of new studies in this field attests, the defense of a doctoral dissertation devoted to the reception of individual institutions of Roman law (S.D. Grin'ko), and so on.

The attitude towards the reception of Roman law in modern Russian jurisprudence is equivocal. Together with recognition of the influence of Roman law on the legislation of the Russian Empire of the nineteenth and early twentieth centuries and stating the similarity of legal norms, institutions, and so on in Roman and modern Russian civil law ${ }^{12}$ (as impartial foreign researchers noted $)^{13}$, there are critical, even cautionary, assessments of the possibility of this phenomenon ${ }^{14}$, attributing to it (indeed, the reception of law in general) the significance of a result of negative ideological influence.

The law not only is among the elements of the socio-political system, but also is an element of social consciousness comprising the spiritual world of man and his world outlook. Law arises in inseparable linkage with religion; then is acquires greater socio-political importance and a philosophical and professional legal comprehension and substantiation; and finally, law becomes an element of social and individual consciousness in the context of the

${ }^{10}$ Дождев Д.В. Римское частное право. М., 1996. С. 4.

${ }^{11}$ Косарев А.И. Римское право. М.: Юридическая лит-ра, 1986. С. 110.

12 Яковлев В.Н. Древнеримское и современное гражданское право России. Рецепция права. 2-е изд. Ижевск, 2004-2005. 2 тома.

${ }_{13}$ Авенариус М. Римское право в России, пер.с нем. Д.Ю. Полдников. М.: Академия, 2008.

${ }^{14}$ Новицкая Т.Е. К вопросу о так называемой рецепции римского права в России. Вестник Московского университета. 2000. № 3. 2000. С. 121-134. 
development of the respective civilization. Because this process is repeatable, just as cycles of civilization can be repeated, the reception of law occurs.

A key moment of characterizing the reception of law is an understanding thereof as part of a general process of renaissances and contacts between a living civilization and a civilization that has receded into the past. Objectively it cannot fail to be a repetitive phenomenon, which is conditioned by the cyclical character of the development of civilizations and the repetition of renaissances and declines. Because the renaissance of the heritage of one culture by another civilization is not a unique event but a historically repetitive process, the reception of law is a repeating phenomenon.

Having regard to the foregoing, the reception of law may be defined as the renaissance thereof, perception of the spirit, ideas, and main principles, and also basic tenets of the law of preceding civilizations by subsequent civilizations at a certain stage of their development in the context of the general process of cyclical renaissances. We have in view not the simple borrowing of the text of legal norms, institutions, and the like, but the perception of basic categories, principles, and conceptions.

In noting the great role of the reception of law (especially Roman) in improving legal systems and ensuring the succession of law with its assistance, we should take into account that this provided a link between legal systems only (vertically) (and merely to a certain extent "horizontally" in derivative receptions). Thus there is the question of the means, or forms, of the interaction of legal systems.

One category which first deserves attention of investigators is "legal acculturation". Various views exist with regard to its definition. However, most widespread is an understanding thereof as a rather complex process. The process of acculturation is defined as:

$\ldots$ the process of mutual influence and the result of this mutual influence of cultures on one another, or the borrowing of a phenomenon from one milieu and introducing it in another milieu, including acclimatization. Consequently, acculturation is a process of borrowing and the borrowing itself as a result - the borrowed object. In other words, acculturation is a process of borrowing expressed in the mastery of innovation by the borrowing group (or individual, people) and adaptation to this"15.

Sometimes acculturation is regarded as an element of social administration which most influences social life in the domain of law-creation and lawapplication $^{16}$.

15 Кузьмин И.А. Юридическая аккультурация и управление профессиональной юридической деятельности. Режим доступу: Advocatkuzmin.ru/ articles/107-article25

16 Кузьмин И.А. Юридическая аккультурация в системе социального управления: автореф. канд. социологических наук. М., 2002. 
The following definition is rather successful: legal acculturation is a relatively autonomous process of continuous interaction of legal systems assuming the use (depending on cultural and historical conditions) of methods differing in the nature and force of impact, a necessary result of which is change of the initial legal culture (or individual elements thereof) or one or both societies coming into contact ${ }^{17}$. Understanding legal acculturation broadly, the author also singles out such forms thereof as borrowing and reception of law ${ }^{18}$.

Sofronova defines legal acculturation as the process of mutual influence of legal systems. She singles out "legal borrowing as a variety of legal acculturation, which assumes the transfer and preservation of legal elements without any changes"19. The position of Sofronova with regard to the correlation of the concepts of "acculturation" and "reception" is interesting. She noted that reception, understood as only voluntary, is a universal variant of acculturation and a perception of another's legal culture not imposed by force. As a generic indicator one may name the unilateral character of borrowing effectuated solely at the initiative of the recipient. Two types of reception are distinguished: (1) horizontal reception: the perception of legal institutions within the framework of a simultaneously operating PSO; (2) vertical borrowing, when there is a change of socio-economic formation assuming the extensive perception of diverse legal phenomena ${ }^{20}$.

In our view, in this position a confusion of concepts is permitted. Insofar as reception, as noted above, is a perception by later legal systems of elements of systems which receded into the past, horizontal reception is impossible by definition. Instead, one may speak of borrowing by one legal system from another.

In evaluating the prospects for the use of the category of acculturation for forming a theory of interaction (or influence) of legal systems, one may assume that the most suitable for this is an understanding of legal acculturation as a universal concept which characterizes this as the infusion of one legal system into another ${ }^{21}$. Some authors in defining legal acculturation as any carrying over of legal forms to another legal milieu distinguish such

17 Абрамов А.Е. Правовая аккультурация (на примере Испании в период Римской Республики): дис.... канд. юрид. наук : 12.00.01. Владимир, 2005. С. 7-8.

18 Абрамов А.Е. Правовая аккультурация (на примере Испании в период Римской Республики): дис.... канд. юрид. наук : 12.00.01. Владимир, 2005. С. 14.

${ }^{19}$ Софронова С.А. Правовое наследие и аккультурация в условиях правового прогресса общества: автореф. дис. ... канд. юрид. наук: 12.00.01. Нижний Новгород, 2000. С. 23.

${ }^{20}$ Софронова С.А. Правовое наследие и аккультурация в условиях правового прогресса общества: автореф. дис. ... канд. юрид. наук: 12.00.01. Нижний Новгород, 2000. С. 27.

${ }^{21}$ Софронова С.А. Правовое наследие и аккультурация в условиях правового прогресса общества: автореф. дис. ... канд. юрид. наук: 12.00.01. Нижний Новгород, 2000. С. 199. 
forms of the last as legal expansion (which is forcible) and reception (voluntary perception of elements of another legal system). Legal expansion is linked with legal transplanting ${ }^{22}$. We note in this connection that the concept "legal transplants", introduced into scholarly discourse of comparativistics ${ }^{23}$ rather long ago, usually is used to designate any borrowings from other legal systems (although sometimes it is used in the meaning of "one of the types of reception"). In other words, they look like a category, in our view, which actually is identical to the concept of "legal acculturation" and different from the concept "reception" 24 .

Thus, one may conclude that these days at the stage of forming a general theory of interaction of legal systems there is no precise, generally-recognized difference of such categories as "legal acculturation", "reception", "legal transplants", "borrowing", and so on.

In our view it would be justified to use the broadest universal term-concept to designate "legal acculturation", by which one should have in view any borrowing of elements of some legal systems by another. The designation "legal transplants" (although the last in the Ukrainian tradition has a certain natural technical hue) is possible. The term-concept "reception of law" rather precisely characterized the borrowing of elements of legal systems of the past by later systems. As regards the borrowing by legal systems one from another which coexist in time (horizontal borrowing), possibly this type of acculturation it would be advisable to call the "interaction (or mutual influence) of legal systems".

\section{Examples of borrowing by different legal systems}

To complete this article we offer examples of borrowings of law by different legal systems in the style of the greatly respected Alan Watson. We recall in particular the borrowing (or reception and interaction) of the law of Antiquity of the achievements of the legal systems of the Near East.

Some students of the history of European law have been critical of the borrowing by the Greek and Romans of laws from peoples who ruled in the Near East: Sumerians, Hittites, Assyrians, Babylonians. However, the evident influence is acknowledged on the forming of European law by the Law of Moses, which initially through the Catholic Church and later especially through the Reformation was extensively perceived by Protestant States ${ }^{25}$. We believe that the fact of influence on the forming of Roman law of norms of the ancient

${ }^{22}$ Третьякова О.Д. Конвергенция в праве: юридическая экспансия. К., 1998. Т. 5. 2002.

${ }^{23}$ Watson A. Legal Transplants: An Approach to Comparative Law. 1974; 2d ed.; 1993.

Books. 24. Режим доступу: https://digitalcommons.law.uga.edu/books/24

${ }^{24}$ Watson A. Legal Transplants and European Private Law, 2000.

${ }^{25}$ Аннерс Е. История Европейского права. М.: Наука, 1996. С. 21. 
Egyptian, Near Eastern, and other civilizations requires no complex argumentation. The Roman jus gentium was nothing other than the aggregate of norms borrowed by the Praetorians from the law of States which proved to be in the sphere of political, economic, or cultural influence of Rome (including Egypt, States of the Near East, and others). Therefore, one may assert that the respective legal systems could not fail to interact with Roman law.

As regards Greece, it is logical to assume that trade and cultural links of early Antiquity and the creation of numerous Greek colonies during the period of "great Greek colonization" of the seventh to sixth centuries bc could not occur without the interaction of legal systems. This also is true of the Hellenist-Eastern syncretism of the Macedonian period. Having regard to the said culture, we shall try to establish the existence of echoes from the spirit, ideas, and legal solutions, and then find an answer to the question whether and when the interaction of legal systems occurred.

Logically, one should begin with the Sumerian local civilization, which existed from approximately the second half of the fourth millennium bc. States belonging to it (the last of them, Achmaemenid Persia, ceased to exist under the blows of the Army of Alexander of Macedonia in 331-330 bc) during his thousand years of history repeatedly entered into contacts with the Hellenic world and Rome. In approximately the sixth to the fifth centuries bc the process of the interaction of these cultures (with the predominance of the Near Eastern tradition) became more active, influencing various aspects of the civilization of Antiquity.

We believe one should speak in the domain of law about the "Near Eastern influence", or, more precisely, the reception of Near Eastern law, and not the interaction of legal systems because European law at that time lagged behind significantly in development. The "archives" of ancient texts written on clay (tablets) found by archaeologists in Mesopotamia testify to the existence in ancient times not only of laws, but to the significant practice of their application, especially in the sphere of trade: texts of contracts, judicial decisions, and the like. The laws of the small city-State Eshnunna date from the twentieth century B.C. Even earlier is the Code of Ur-Nammu, which operated from about 2112 to 2095 B.C.

The Code of Ur-Nammu astonishes for its precise formulation of the basic idea of law, which comprises the essence of law to the present time. The Preamble to the Code notes that its purpose is the "establishment in the country of justice and the eradication of arbitrariness and lawlessness". In our view, one may see in this formulation the sources of the idea of a rule-of-law State or, in any event, of certain principles of the last. The idea of a legal and partially de facto equality of private persons is rather precisely expressed in this Code: these laws are introduced so that "an orphan does not become the 
booty of the wealthy, and a widow the booty of the strong", "to "judge by just laws", to "make judicial decisions permanent".

Indeed, the ruler Ur-Nammu was not original in the formulations of his laws: as follows from the inscriptions found in Lagash and made about 2350 bc, then the Ur-Nammuians "restored freedom" and by the force of the laws established by them arranged that no "priest of supply entered the garden of the mother of a poor peasant" and that when "the son of a poor man sets a net, no one will take his fish".

However, we are more interested not in these ancient civilizations themselves and their law, but in the possible link between the law of these cultures and Antiquity. It is unlikely that the Code of Ur-Nammu could have exerted direct influence on the forming of legislation of the ancient Mediterranean. This also is true of the code of laws of the ruler Lipit-Ishtar, of the Isin Dynasty, and the code of laws from Ennusha. Obviously, there must be some connecting, mediating link: a tradition which would take into account principles inherent in Sumerian law and existing in a State or group of States that might have contacts with ancient civilization. We refer to a reception of the law of Near Eastern systems in the law of Antiquity.

The reception of law by Ancient Greece is no less a clear example. On the whole by his laws Solon began the creation of the systematic law of Athens which expressed together with other norms the determining spirit of this cityState. He was concerned with legal enlightenment: his laws written on wooden blocks were placed in the city so that each had the possibility to be familiar with their content ${ }^{26}$.

From the legal point of view, the reforms of Solon marked the completion of rule which was effectuated through the mediation of decrees not provided for and not permanent and the commencement of rule with the assistance of written, stable law. So stable that five centuries later Cicero had the complete right to assert that the laws of Solon are, as earlier, in force in Athens ${ }^{27}$.

Sparta was the antipode of Athens in the realm of legal regulation, the chief competitor not only in politics, but also in ideology.

According to Herodotus, the Lacedonians had the worst laws in comparison with all other Hellenes. They communicated neither among themselves nor with foreigners on these matters. Only when Lycurgus received from the Delphi Oracle so-called "Rhetra", which is treated variously: either the laws proper of Lycurgus, or divine sanction for them to be drawn up (Herodotus, 1.65). In any event, the desire to place a sacral foundation under the collection of legislation, which we encountered in speaking of Mesopotamia, Judea, and Egypt, was expressively set

\footnotetext{
${ }^{26}$ Беккер Ф. Мифы древнего мира. Саратов: Надежда, 1995. С. 187.

${ }^{27}$ Дюрант В. Жизнь Греции. М.: КРОН-ПРЕСС, 1997. С. 126.
} 
out. Indeed, Herodotus gives another version: "Lycurgus brings his laws from Crete. Here we again encounter an interesting phenomenon: the wish to "add solidarity" to law-creation efforts by means of a reference to a foreign origin. Something similar occurs when defining the genesis of Roman law (Laws of the Twelve Tables).

With regard to Roman law in jurisprudence the thought is embedded of the absolute predominance of it over all other legal systems of that time and the uniqueness of the phenomenon of the forming of Roman private law, which over time became the basis of virtually all European systems of law (although the fact is not denied of the borrowing of legal solutions from foreign law, which led finally to the creation with the assistance of the Praetorians of the jus gentium, which over time became an element of Roman private law). As a rule, the testimony of Roman sources fixed in the Digests of Justinian (1.2.2.4) concerning the derivative nature of the first codification in Rome the Laws of the Twelve Tables - is critically perceived: many specialists believe that reference is being made merely to inheriting the "Greek fashions" and underpinning own laws with the authority of Hellenic $\operatorname{law}^{28}$. And although some do not doubt that the decemviri sent a commission of three persons to Greece in order to study the laws of Solon ${ }^{29}$, but the majority of Romanists do not take into account the "Greek trace", stating that the decemviri simply "elaborated" the Laws of the Twelve Tables.

We believe that in assessing the genesis of Roman private law, one should recall the remark of Utchenko about the erroneousness of deprecating the originality of Roman culture and of underestimating the process of the penetration into that culture of Hellenist influences. One should also note the erroneousness of portraying these influences as "purely Greek" because the culture of the East was introduced in Rome via Greece ${ }^{30}$.

Taking into account the peculiarities of the development of local proto-ancient civilizations and their interaction with ancient cultures provides a basis for asserting that together with the reception of certain world outlook, ethical legacies of the East, during Antiquity the reception of law occurs, in which Greece acts as the middleman. We believe that this does not reduce at all the importance of the achievements of the jurisprudence of Ancient Rome; however, it does make it possible to justly assess the trends of development of the legal systems of Europe.

The concepts of Roman society concerning justice, good, and evil, orderliness and abuses, and so on were formed under the influence of ethical

${ }^{28}$ Покровский И. А. История Римского права. СПб.: Издательско-торговый дом Летний Сад, 1998. С. 121.

${ }^{29}$ Пухан И., Поленак-Акимовская М. Римское право. М.: Зерцало, 1999. С. 21-22.

${ }^{30}$ Утченко С.Л. Древний Рим. М.: Наука, 1969. С. 218. 
tenets of ancient Greek philosophy. According to the well-known utterance of the Roman poet, Horatio, Greeks taken into captivity themselves captured the victors. This occurred because Hellenist philosophical thought elaborated the doctrine, synthesized views which responded not only to common trends in the development of ancient civilization, but better expressed the aspirations of Rome and the essence thereof to the times. In this capacity stoicism crossed into Roman philosophy ${ }^{31}$. With its assistance the philosophical base was brought under the Roman ideal of the good citizen, vir bonus, and the cosmopolitanism of the Stoics was transformed into an ordinary version for Romans concerning the advisability and necessity of the existence of their State as a world State ${ }^{32}$. Epicureanism was also popular in Rome with its accessible doctrine that for happiness one needs only honor and justice, and on this basis one may enjoy life and display concern for own advantage. Societies arise at the initiative of people who try to ensure self-defense, mutual assistance, and exchange of knowledge and services. Society should be based on compliance by all of its members with an agreement not to do harm to one another and to assist the weak ${ }^{33}$.

\section{CONCLUSIONS}

In assessing the principles of the Roman philosophy of law from the positions of their correlation with those principles which had been formulated much earlier in the ethics of Hellenism, and even earlier in the civilizations of the Near East, we may justly conclude with regard to the reception of the last in the law of Rome which occurred in the context of the general Renaissance of Greek culture. To be sure, they were developed and modernized with respect to the needs of Roman (Late Antiquity) civilization. This is an indicator of reception which, as noted above, distinguishes it from restoration, evocation, and so on.

The adaptation of these moral and ethical principles and legal norms to morality, needs, and mentality of the Romans also occurred. Under the influence of Stoic philosophy, the Roman jurists elaborated the doctrine of natural law; the view of the Epicureans found reflection in the recognition of individualism and sovereignty of the person, as grounds for the origin of the right of private ownership and certain other institutions of positive law.

It is interesting to note that Ulpian suggested a solution which fundamentally changes the boundaries of defining subjects of law: "A slave may not be from the standpoint of civil law a party to a contractual obligation;

\footnotetext{
${ }^{31}$ Асмус Б.Ф. Античная философия. М.: Высшая школа, 1976. С. 454.

32 Утченко С.Л. Политическая учения Древнего Рима. III-I вв. до н. э. М.: Наука, 1977. C. 89-92.

${ }^{33}$ Titus Lucretius Carus, De rerum natura. Libri VI, 1473.
} 
however, in the natural law aspect, he may oblige and be obliged" (D.44.7.14). In the context of this study, attention should be drawn to the similarity of the methodological approaches of Ulpian and Solon, and even earlier, the creators of the law of Babylon, who thought virtually in the same manner. Thus, we have an example of the reception of the principles of an ancient system of law in a later legal system when determining the status of a person, it being especially interesting that in either instance a struggle of principles of natural and "normative" law occurs.

The characteristic peculiarities of the law of Ancient Rome together with the genesis of its philosophy testify to the process of the Greek Renaissance, which occurred at the turn of the millennia a reception of law took place, in the course of which Greece acted not only as a recipient, but as a link which mediated the reception of Near Eastern law. The reception of law occurred in various forms, among which the leading role was played by the perception of the philosophical foundation and ideas of natural rights of the private person. However, the borrowing of certain legal solutions of principle also occurred, and the introduction of individual institutions, categories, and concepts of Greek law, and so on.

Interesting examples of borrowings of law exist with regard to Byzantium. Justinian's systematization may be characterized as the aggregate of codification (code) and attempts to receive Roman law (especially private) which proceeded in the form of a compilation of fragments from Roman sources (digests and Institutes). This first attempt at reception of Roman law created the foundation for its further receptions in various forms, in different countries, various civilizations. Students of the history of Byzantium drew attention to the fact that supposedly in foreseeing the future impoverishment of spiritual life and the decline of Enlightenment, Justinian rescued for the future the majestic fruits of the creativity of the Roman people in the sphere of legal consciousness, thanks to which western peoples gradually departing from barbarism, were imbued with the idea of the rule-of-law State and completed the reception of Roman law ${ }^{34}$.

An instance of borrowing from other legal systems with a view to improving own legislation in the East is mentioned in the Ecloga ton nomon or the Ecloga Leonis of the Byzantine Emperor Leo III. Although the Ecloga is criticized because it mixes together extracts from the Digest, Institutes, Code, and compilations of agricultural, maritime, and military law, and also the Commandments of Moses, edited and presented as legal norms, from the standpoint of the issues addressed in the present article, they are a remarkable example of the interaction of legal systems.

\footnotetext{
${ }^{34}$ Кулаковский Ю.А. История Византии. СПб., 1996. Т. ІІ. С. 268.
} 


\section{SUMMARY}

The article considers the problem of adaptation of law as the mode of the interaction of legal systems. It analyzes the conception of the reception of Roman private law. It is mentioned that the reception of Roman law is relegated to the most noteworthy phenomena in the development of European civilizations during the last millennia and a half. Occurring in various forms, against the background of the operation of different geopolitical, economic, social, and spiritual factors, they reflect the general trend of the cyclical development of cultures which consists in forming so-called "universal human values". In assessing the principles of the Roman philosophy of law from the positions of their correlation with those principles which had been formulated much earlier in the ethics of Hellenism, and even earlier in the civilizations of the Near East, we may justly conclude with regard to the reception of the last in the law of Rome which occurred in the context of the general Renaissance of Greek culture. To be sure, they were developed and modernized with respect to the needs of Roman (Late Antiquity) civilization. This is an indicator of reception which distinguishes it from restoration, evocation, and so on.

\section{REFERENCES}

1. Муромцев С. Рецепция римского права на Западе. М.: Тип. А.И. Мамонтова и К, 1886.155 с.

2. Моддерман В. Рецепция римского права: пер. А. Каминка. СПб., $1888.133 \mathrm{c}$.

3. Бек В.А. Рецепция римского права в Западной Европе: автореф. дисс. ... канд. юрид. наук. Львов, 1950. 16 с.

4. Харитонов С.О. Рецепція римського приватного права (теоретичні та історико-правові аспекти). Одеса, 1997. 283 с.

5. Харитонов Є.О., Харитонова О.І. Рецепції приватного права: парадигма прогресу. Кіровоград: Центр.-Укр. вид-во, 1999. 144 с.

6. Томсинов В.А. Рецепция Римского права в Западной Европе". Древнее право. 1998. №. 1. С. 169-175.

7. Новгородцев П.И. Историческая школа юристов. СПб.: Лань, 1999. $192 \mathrm{c}$.

8. Иеринг Р. фон. Историческая школа юристов. В кн.: Савиньи Ф.К. Система современного римского права: пер. Г. Жигулин. 2011. С. 73-101.

9. Иеринг Р. фон. Дух римского права В кн.: Избранные труды. СПб., 2006. Т. II. С. 21-316.

10. Азаревич Д.И. Из лекций по римскому праву. Одесса, 1885. 118 с.

11. Азаревич Д.И. Значение римского права. Одесса, б.г.

12. Дювернуа Н. Значение римского права для русских юристов. Ярославль: Тип. Г. Фальк. 1872.25 с. 
13. Летяев В.А. Рецепция римского права в России XIX - начала $\mathrm{XX}$ в. (историко-правовой аспект): автореф. дисс. ... доктора юрид.наук. Саратов. 2001.44 c.

14. Koschaker P. Europa und das römische Recht. 1958.

15. Koschaker P. Die Krise des römischen Rechts und die romanistische Rechtswissenschaft. 1938.

16. Дождев Д.В. Римское частное право. М., 1996. 704 с.

17. Косарев А.И. Римское право. М.: Юридическая лит-ра, 1986. $158 \mathrm{c}$.

18. Яковлев В.Н. Древнеримское и современное гражданское право России. Рецепция права. 2-е изд. Ижевск, 2004-2005. 2 тома.

19. Avenarius М. Римское право в России, пер.с нем. Д.Ю. Полдников. М.: Академия, 2008. 156 с.

20. Новицкая Т.Е. К вопросу о так называемой рецепции римского права в России. Вестник Московского университета. 2000. № 3. 2000. C. $121-134$.

21. Кузьмин И.А. Юридическая аккультурация и управление профессиональной юридической деятельности. Режим доступу: Advocatkuzmin.ru/articles/107-article25

22. Кузьмин И.А. Юридическая аккультурация в системе социального управления: автореф. канд. социологических наук. М., 2002. 22 с.

23. Абрамов А. Е. Правовая аккультурация (на примере Испании в период Римской Республики): дис.... канд. юрид. наук : 12.00.01. Владимир, 2005. $183 \mathrm{c.}$

24. Софронова С.А. Правовое наследие и аккультурация в условиях правового прогресса общества: автореф. дис. ... канд. юрид. наук: 12.00.01. Нижний Новгород, 2000. 30 с.

25. Карбонье Ж. Юридическая социология. М.: Прогресс, 1980. 351 с.

26. Третьякова О.Д. Конвергенция в праве: юридическая экспансия. К., 1998. Т. 5. 2002.720 c.

27. Watson A. Legal Transplants: An Approach to Comparative Law. 1974; 2d ed.; 1993. Books. 24. Режим доступу: https://digitalcommons.law.uga.edu/ books $/ 24$

28. Watson A. Legal Transplants and European Private Law, 2000.

29. Аннерс Е. История Европейского права. М.: Наука, 1996. 395 с.

30. Беккер Ф. Мифы древнего мира. Саратов: Надежда, 1995. 720 с.

31. Дюрант В. Жизнь Греции. М.: КРОН-ПРЕСС, 1997. 704 с.

32. Покровский И. А. История Римского права. СПб.: Издательскоторговый дом Летний Сад, 1998. 560 с.

33. Пухан И., Поленак-Акимовская М. Римское право. М.: Зерцало, 1999. $448 \mathrm{c}$. 
34. Утченко С.Л. Древний Рим. М.: Наука, 1969. 324 с.

35. Асмус Б.Ф. Античная философия. М.: Высшая школа, 1976. 543 с.

36. Утченко С.Л. Политическая учения Древнего Рима. III - I вв. До н. э. М.: Наука, 1977. 254 с.

37. Titus Lucretius Carus, De rerum natura. Libri VI, 1473.

38. Кулаковский Ю.А. История Византии. СПб.,1996. Т. ІІ. 400 с.

Information about the author: Kharytonova O. I., Doctor of Legal Sciences, Professor, Corresponding Member. NAPrN Ukraine, Head of the Department of Intellectual Property Law and Law of Corporations, National University "Odessa Law Academy" 